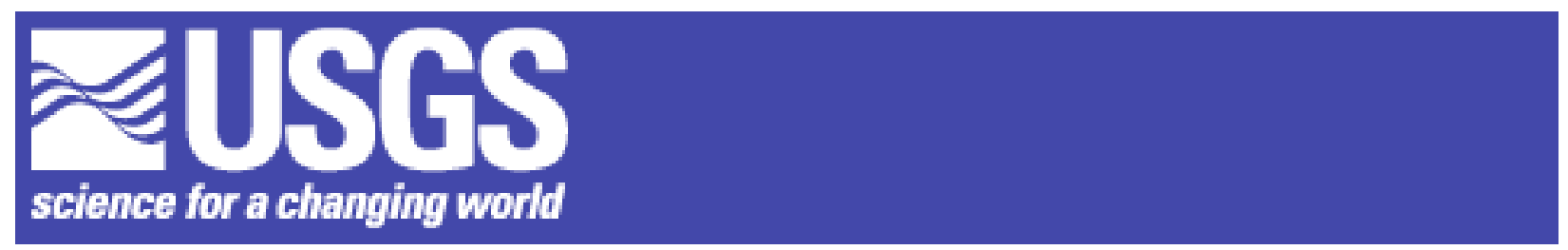

U.S. Geological Survey Open-File Report OF 03-8

\title{
GULF OF MEXICO PLANKTIC FORAMINIFER CORE-TOP CALIBRATION DATA SET: RAW DATA
}

\section{By Harry J. Dowsett ${ }^{1}$, Charlotte A. Brunner ${ }^{2}$, Stacey Verardo ${ }^{1}$, and Richard Z. Poore}

\section{INTRODUCTION AND BACKGROUND}

Paleoceanographers use the distribution of planktic foraminifers in sediment samples to estimate past oceanographic and paleoclimatic conditions (see Murray, 1995 for review). Analysis of climate and environmental variability on the decadal to millenial scale requires a taxonomically stable and well-dated core-top calibration data set. Databases used in global reconstructions of the last glacial maximum (Cline and Hays, 1976; CLIMAP, 1976; 1981), last interglacial (CLIMAP, 1984), and middle Pliocene (Dowsett et al., 1999) do not always meet these requirements. In this report we present planktic foraminifer faunal census data and AMS ${ }^{14} \mathrm{C}$ data which can be be used in investigations of climate variability in the Gulf of Mexico region (eg. Poore et al., in review). More comprehensive interpretation and analysis of these data, aimed at

\footnotetext{
${ }^{1}$ U.S. Geological Survey, 926A National Center, Reston, Virginia, 20192

${ }^{2}$ Department of Marine Science, University of Southern Mississippi, Stennis Space Center, Mississippi, 39529
} 
developing a temporally and taxonomically stable data set will follow in other publications (see Dowsett et al., 2002).

\section{MATERIALS \& METHODS}

Core-top samples included in this report were originally retreived during Gulf of Mexico cruises of the $R V$ Vema and $R V$ Robert Conrad (Lamont Doherty Earth Observatory, LDEO), $R V$ Trident (University of Rhode Island, URI), $R V$ Gyre (Texas A\&M University, TAMU), $R V$ Knorr (Woods Hole Oceanographic Institute, WHOI), $R V$ Ida Green (University of Texas Marine Science Institute) and the $R V$ Marion-Dufresne (French Polar Institute), dating as far back as 1954. Samples are from piston cores,

trigger weight cores or gravity cores. Core sites selected for this study represent a range of depth and environment and are distributed througout the Gulf of Mexico (Figure 1 and Appendix 1).

The faunal data assembled here are a combination of planktic foraminifer counts from Gulf of Mexico core-top samples processed by the U.S. Geological Survey (USGS), URI, and Brown University (under the direction of Nilva Kipp). The processing technique is standard but differences between the labs are noted below. Additional information regarding methodology can be found in Imbrie \& Kipp (1971), Brunner and Cooley (1976), Brunner (1979, 1982), and Dowsett \& Poore (2001). Careful attention was paid to the taxonomic concepts of the various authors so that the resulting data set is internally taxonomically-consistent.

Raw samples aquired by the USGS were processed by first oven drying $\left(\leq 50^{\circ} \mathrm{C}\right)$ and then soaking in dilute Calgon or $\mathrm{H}_{2} \mathrm{O}_{2}$ solution for several hours to disaggregate the sediment. Disaggregated sediment was washed through a $63 \mu \mathrm{m}$ mesh and oven dried at $\leq 50^{\circ} \mathrm{C}$. Dry residue was then dry-sieved at $150 \mu \mathrm{m}$ with the $>150 \mu \mathrm{m}$ fraction reserved for faunal analysis. When necessary ( $>300$ individuals in the $>150 \mu \mathrm{m}$ fraction) 
samples were split using a CARPCO or OTTO microsplitter to obtain a representative sample of 300 specimens. Next (for samples analyzed at the USGS), individuals were fixed on a standard 60-square micropaleontological slide based upon their designation as species. Samples analyzed at URI were counted directly from a strew on a tray.

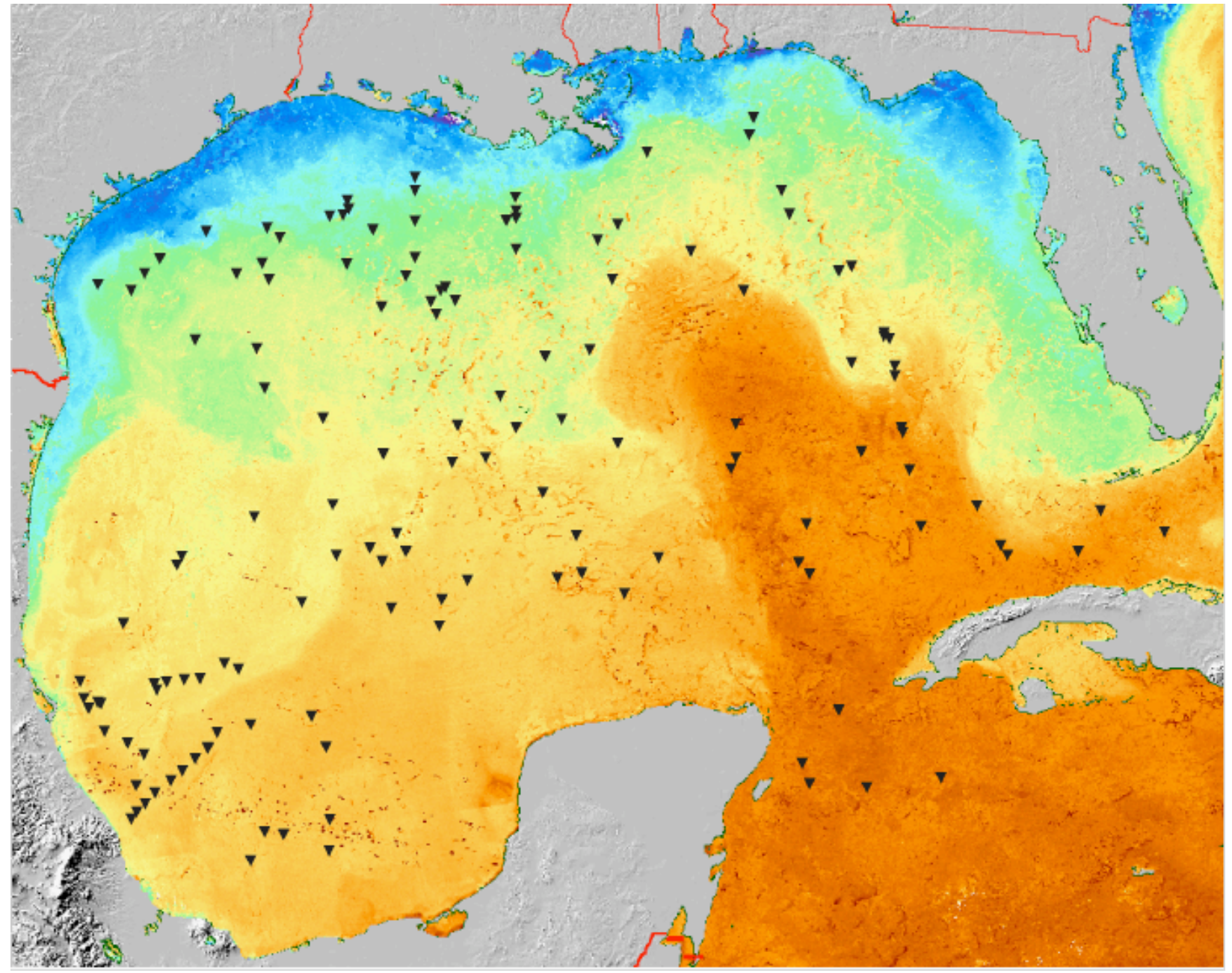

Figure 1. Distribution of samples within the Gulf of Mexico displayed on January 2001 mean sea-surface temperature (SST) map. Orange colors represent warmest SST and highlite the advection of warm water into the Gulf of Mexico from the Caribbean and the position of the Loop Current. (SST map provided by Space Oceanography Group, Johns Hopkins University Applied Physics Laboratory) 


\section{FAUNAL DATA}

The taxonomies of Parker $(1962,1967)$, Blow (1969), Kennett and Srinivasan (1983), and informal notes of Nilva Kipp, were employed for identification. Faunal census data are reported here using the following taxonomic categories:

Orbulina universa d'Orbigny

Globigerinoides conglobatus (Brady)

Globigerinoides ruber (d'Orbigny). White and pink varieties of this species are tallied together.

Globigerinoides tenellus Parker

Globigerinoides sacculifer (Brady). We include in this category specimens assignable to Globigerinoides quadrilobatus (d'Orbigny) and Globigerinoides trilobus (Reuss).

Sphaeroidinella dehiscens (Parker \& Jones)

Globigerinella aequilateralis (Brady)

Globigerinella calida (Parker)

Globigerina bulloides d'Orbigny

Globigerina falconensis Blow

Globigerina digitata Brady

Globigerina rubescens Hofker

Turborotalita quinqueloba (Natland)

Neogloboquadrina pachyderma (Ehrenberg). Right and left coiling varieties are counted separately in this report.

Neogloboquadrina dutertrei (d'Orbigny)

Globorotaloides hexagona (Natland) 
Pulleniatina obliquiloculata Parker \& Jones

Globorotalia inflata (d'Orbigny)

Globorotalia truncatulinoides (d'Orbigny). Right and left coiling varieties are counted separately in this report.

Globorotalia crassaformis (Galloway \& Wissler)

Neogloboquadrina pachyderma - Neogloboquadrina dutertrei (P - D ) intergrade. Specimens of right-coiling Neogloboquadrina with more than four chambers in the final whorl, transitional between Neogloboquadrina pachyderma (Ehrenberg) and Neogloboquadrina dutertrei (d'Orbigny).

Globorotalia hirsuta (d'Orbigny)

Globorotalia scitula (Brady)

Globorotalia menardii (Parker, Jones, and Brady) s.l. Our Gl. menardii complex includes Gl. menardii, Globorotalia tumida (Brady) s.l. and Globorotalia ungulata Bermudez.

Candeina nitida d'Orbigny

Globigerinita glutinata (Egger) s.l.

Hastigerina pelagica (d'Orbigny)

Other. Unidentified specimens or specimens that are rare within the Gulf of Mexico assemblages.

Raw counts of planktic foraminifers in each of 135 samples are provided in Appendix 1.

\section{AMS ${ }^{14}$ C DATA}

Archival core-top material from many of the cores shown on Figure 1 and listed in Appendix 1, is no longer available. Therefore, direct dating of core-top assemblages is for the most part, impossible. In many cases, we were able to obtain samples close to the core-top and estimate core-top ages by extrapolation. Several numerical techniques were devised to determine the probability of assemblages representing "modern" core-top conditions and will be discussed elsewhere (see also Dowsett et al., 2002). 
Samples selected for Accelerator Mass Spectrometry (AMS) ${ }^{14} \mathrm{C}$ dating were processed as indicated above. Unless indicated otherwise (Table 1), dates were obtained from mixed planktic foraminifers hand picked from the $>150 \mu \mathrm{m}$ washed residue. Graphite targets for AMS dating were made at the USGS in Reston, Virginia. The carbon from these samples was captured as $\mathrm{CO}_{2}$ by acidification of the entire sample with $85 \%$ phosphoric acid $\left(\mathrm{H}_{2} \mathrm{PO}_{4}\right)$ in a vacuum chamber. The $\mathrm{CO}_{2}$ was then dried by forcing the gas through a bath cooled (using alcohol and dry ice) to approximately $80^{\circ} \mathrm{C}$. The dried $\mathrm{CO}_{2}$ was converted to pure carbon in the form of graphite by placing a measured volume (equivalent to $1 \mathrm{mg}$ carbon) in a chamber with iron powder, hydrogen, and zinc as a catalyst at $575^{\circ} \mathrm{C}$ for ten hours. The sample carbon (precipitated on the iron) was pressed into aluminum targets for AMS analysis.

Dating was done at the Lawrence Livermore Laboratory Center for Accelerator Mass Spectrometry (CAMS) in Livermore, CA (Roberts et al., 1997). Ages were reported in radiocarbon years (BP) using the Libby half-life of 5568 years. AMS ${ }^{14} \mathrm{C}$ dates were converted to calendar years (BP) by calibration to the INTCAL98 database (Stuiver et al., 1998) and a estimated marine reservoir correction of 400 years.

Table 1 lists results of AMS ${ }^{14} \mathrm{C}$ dating.. An initial analysis of some of the data presented here can be found in Dowsett et al. (2002).

Table 1. AMS ${ }^{14} \mathrm{C}$ results. Samples composed of mixed planktics unless otherwise noted.

CORE INTERVAL(CM) AGE(BP $)^{\square} \pm(\text { YRS) CALYR(BP })^{\text {b,c }}$ COMMENTS

\begin{tabular}{llllll}
\hline RC09-17 & $8-10$ & 1595 & 40 & 725 & \\
RC09-17 & 20 & 4210 & 45 & 3736 \\
RC10-262 & $10-12$ & 2930 & 40 & 2176 & \\
RC10-262 & $30-32$ & 7100 & 35 & 7235 & \\
RC10-262TW & $0-1$ & 3515 & 35 & 2870 & \\
RC10-263 & $9-11$ & 3500 & 30 & 2856 & \\
RC10-263 & $34-36$ & 6270 & 30 & 6279 & \\
RC10-264 & $17-19$ & 18185 & 50 & 20570 \\
RC10-264 & $38-40$ & 27640 & 120 & -- & too old to be converted \\
RC10-265 & $15-17$ & 1855 & 40 & 981 & \\
RC10-265 & $34-36$ & 4590 & 40 & 4266 & \\
RC10-268 & $13-15$ & 2950 & 40 & 2246 & \\
RC10-268 & $34-36$ & 4740 & 35 & 4443 & \\
& & & & 6
\end{tabular}




\begin{tabular}{|c|c|c|c|c|c|}
\hline RC10-270 & $10-12$ & 3295 & 40 & 2702 & \\
\hline RC10-270 & $31-33$ & 3085 & 40 & 2343 & \\
\hline RC12-09 & $15-17$ & 2290 & 30 & 1417 & \\
\hline RC12-09 & $36-38$ & 3815 & 30 & 3306 & \\
\hline RC12-05 & $10-12$ & 2435 & 40 & 1593 & \\
\hline RC12-05 & $30-32$ & 3700 & 40 & 3150 & \\
\hline RC12-07 & $18-20$ & 1455 & 40 & 633 & \\
\hline RC12-07 & $37-39$ & 2635 & 40 & 1832 & \\
\hline RC12-07TW & $0-1$ & 1680 & 35 & 824 & \\
\hline RC12-10 & $0-2$ & 940 & 35 & 167 & \\
\hline RC12-10 & $16-18$ & 1390 & 30 & 557 & \\
\hline RC12-10 & $50-51$ & 3185 & 60 & 2489 & \\
\hline RC12-10 & $100-101$ & 5325 & 60 & 5276 & \\
\hline RC12-10 & $134-136$ & 6985 & 50 & 7139 & \\
\hline RC12-10 & $172-174$ & 9350 & 40 & 9528 & \\
\hline RC12-10 & $210-212$ & 12085 & 45 & 13153 & \\
\hline RC12-10 & $254-256$ & 15710 & 45 & 17722 & \\
\hline RC12-11 & $50-51$ & 5470 & 200 & 5442 & \\
\hline RC12-11 & $100-101$ & 9595 & 75 & 9826 & \\
\hline RC12-11TW & $0-1$ & 1280 & 35 & 500 & \\
\hline VM03-32 & $18-20$ & 6255 & 40 & 6272 & \\
\hline VM03-32 & $108-110$ & 9395 & 40 & 9613 & \\
\hline VM03-35 & $8-10$ & 4080 & 35 & 3584 & \\
\hline VM03-42 & $10-12$ & 6325 & 40 & 6311 & \\
\hline VM03-42 & $46-48$ & 4835 & 30 & 4574 & \\
\hline VM03-45 & $10-12$ & 6400 & 40 & 6402 & \\
\hline VM03-45 & $35-37$ & 9630 & 35 & 9835 & \\
\hline VM03-49 & $39-41$ & 8845 & 50 & 8932 & \\
\hline VM03-49 & 89-91 & 3875 & 40 & 3351 & \\
\hline VM03-69 & $47-48$ & 3430 & 65 & 2774 & \\
\hline VM03-69 & $97-98$ & 5460 & 120 & 5437 & \\
\hline VM03-96 & 15 & 1755 & 40 & 910 & \\
\hline VM03-96 & 30 & 3955 & 40 & 3438 & \\
\hline VM03-123 & 5 & 9465 & 40 & 9786 & \\
\hline VM03-123 & 23 & 26590 & 90 & -- & too old to be converted \\
\hline VM03-146 & $8-10$ & 22580 & 70 & -- & too old to be converted \\
\hline VM03-146 & $30-32$ & 32430 & 160 & -- & too old to be converted \\
\hline VM24-22 & $9-11$ & 1880 & 35 & 1030 & \\
\hline VM24-22 & $34-36$ & 7385 & 120 & 7473 & \\
\hline VM24-22TW & $0-1$ & 2640 & 35 & 1842 & \\
\hline VM26-142 & $0-1$ & 1860 & 40 & 987 & \\
\hline VM26-142 & $30-32$ & 4400 & 40 & 3985 & \\
\hline GY97-06PC20 & $11-12$ & 830 & 30 & -- & \\
\hline GY97-06PC20 & 40 & 2340 & 40 & 1501 & \\
\hline GY97-06PC20 & $77-78$ & 3540 & 30 & 2914 & \\
\hline
\end{tabular}




\begin{tabular}{|c|c|c|c|c|c|}
\hline GY97-06PC20 & 100 & 4900 & 40 & 4698 & \\
\hline GY97-06PC20 & 140 & 6870 & 40 & 6950 & \\
\hline GY97-06PC20 & 160 & 8300 & 40 & 8357 & \\
\hline GY97-06PC20 & $185-186$ & 10050 & 35 & 10310 & \\
\hline IG19-3-35 & $20-21$ & 3570 & 40 & 2946 & \\
\hline IG19-3-35 & $60-61$ & 7710 & 40 & 7752 & \\
\hline TR126-10 & $118-120$ & 26100 & 90 & -- & too old to be converted \\
\hline TR126-10 & $118-120$ & 29910 & 130 & -- & Globorotalia truncatulinoides (too old) \\
\hline TR126-10 & $118-120$ & 34380 & 340 & -- & Neogloboquadrina dutertrei (too old) \\
\hline TR126-10 & $200-202$ & 49100 & 1100 & -- & too old to be converted \\
\hline TR126-10 & $400-402$ & 49100 & 1100 & -- & too old to be converted \\
\hline TR126-10 & $700-702$ & 49300 & 1200 & -- & too old to be converted \\
\hline TR126-11 & $100-102$ & 30600 & 140 & -- & too old to be converted \\
\hline TR126-11 & $350-352$ & 46580 & 890 & -- & too old to be converted \\
\hline TR126-23 & $0-1$ & 1910 & 35 & 1053 & \\
\hline TR126-30 & $0-1$ & 4865 & 35 & 4625 & \\
\hline TR126-33 & $0-1$ & 4920 & 50 & 4743 & Globigerinoides ruber and G. sacculifer \\
\hline KN159JPC6TW & $0-1$ & 2210 & 40 & 1338 & \\
\hline KN159JPC6 & $0-1$ & 940 & 35 & 167 & \\
\hline KN159JPC6 & 5 & 730 & 35 & -- & too young to be converted \\
\hline KN159JPC6 & 20 & 1145 & 40 & 410 & \\
\hline KN159JPC6 & $49-50$ & 1820 & 35 & 951 & \\
\hline KN159JPC6 & $100-101$ & 2610 & 35 & 1813 & \\
\hline KN159JPC6 & $128-129$ & 3460 & 35 & 2811 & \\
\hline KN159JPC31-1-1 & 3-4 & 1510 & 40 & 658 & \\
\hline KN159JPC31-1-3 & $0-1$ & 6100 & 30 & 6111 & \\
\hline KN159JPC33 & $0-1$ & 730 & 30 & -- & too young to be converted \\
\hline KN159JPC33 & $60-61$ & 2290 & 40 & 1417 & \\
\hline KN159JPC34 & $2-3$ & 610 & 40 & -- & too young to be converted \\
\hline KN159JPC34 & $81-82$ & 3630 & 40 & 3039 & \\
\hline KN159JPC35 & 5 & 900 & 40 & 123 & \\
\hline KN159JPC35 & 20 & 1495 & 40 & 651 & \\
\hline GY94H2GC2 & $11-13$ & 540 & 50 & -- & too young to be converted \\
\hline GY94H2GC2 & $11-13$ & 940 & 50 & 167 & benthics \\
\hline GY94H2GC2 & $13-14.5$ & 580 & 40 & -- & too young to be converted \\
\hline GY94H2GC2 & $46-48$ & 1330 & 50 & 524 & \\
\hline GY94H2GC2 & $46-48$ & 1520 & 40 & 662 & benthics \\
\hline GY94H2GC2 & $48-50$ & 1320 & 30 & 518 & \\
\hline GY94H2GC2 & $48-50$ & 1510 & 30 & 658 & benthics \\
\hline GY94H8GC8 & $14-16$ & 470 & 60 & -- & too young to be converted \\
\hline GY94H8GC8 & $46-48$ & 760 & 50 & -- & too young to be converted \\
\hline GY94H17GC16 & $10-12$ & 400 & 60 & -- & too young to be converted \\
\hline GY94H17GC16 & $10-12$ & 630 & 50 & -- & benthics (too young) \\
\hline GY94H17GC16 & $12-14$ & 390 & 40 & -- & too young to be converted \\
\hline GY94H17GC16 & $12-14$ & 620 & 30 & -- & benthics (too young) \\
\hline
\end{tabular}




$\begin{array}{llllll}\text { GY94H17GC16 } & 49-51 & 790 & 40 & - & \text { too young to be converted } \\ \text { GY94H17GC16 } & 49-51 & 940 & 50 & 167 & \text { benthics } \\ \text { GY94H17GC16 } & 51-53 & 870 & 40 & 66 & \\ \text { GY94H17GC16 } & 51-53 & 1160 & 40 & 421 & \text { benthics } \\ \text { GY94H23GC23 } & 11-13 & 610 & 40 & - & \text { too young to be converted } \\ \text { GY94H23GC23 } & 11-13 & 640 & 50 & -- & \text { benthics (too young) } \\ \text { GY94H23GC23 } & 48-49 & 1140 & 50 & 404 & \\ \text { GY94H23GC23 } & 48-49 & 1390 & 50 & 557 & \text { benthics } \\ \text { GY94H39GC36 } & 12-14 & 1300 & 50 & 509 & \text { benthics } \\ \text { GY94H39GC36 } & 30-32 & 1860 & 50 & 987 & \text { benthics } \\ \text { GY94H50GC43 } & 10-12 & 1590 & 40 & 721 & \\ \text { GY94H50GC43 } & 40-42 & 3700 & 50 & 3150 & \\ \text { GY94H50GC43 } & 40-42 & 4640 & 40 & 4351 & \text { benthics } \\ \text { GY94H114GC81 } & 6-8 & 1610 & 40 & 736 & \\ \text { GY94H114GC81 } & 6-8 & 2360 & 50 & 1515 & \text { benthics } \\ \text { GY94H114GC81 } & 16-18 & 1790 & 40 & 928 & \\ \text { GY94H114GC81 } & 16-18 & 2800 & 40 & 2020 & \text { benthics } \\ \text { GY94H121GC88 } & 10-12 & 610 & 40 & -- & \text { too young to be converted } \\ \text { GY94H121GC88 } & 42-44 & 1300 & 40 & 509 & \\ \text { GY94H121GC88 } & 42-44 & 1650 & 30 & 781 & \text { benthics } \\ \text { MD02-2553 } & 5-6 & 605 & 40 & - & \text { too young to be converted } \\ \text { MD02-2553 } & 100-101 & 3265 & 40 & 2685 & \\ \text { MD02-2553 } & 200-201 & 5155 & 40 & 4987 & \\ \text { MD02-2553 } & 300-301 & 8520 & 45 & 8582 & \end{array}$

${ }^{a}$ radiocarbon years

${ }^{\mathrm{b}}$ calendar years (Stuiver et al., 1998)

${ }^{c}$ samples with no entry in this column are too young/old to be calibrated

\section{ACKNOWLEDGEMENTS}

We thank Lynn Wingard and Thomas Cronin for thoughtful reviews of this work. We thank Bethany Boisvert, Kate Pavich, and Jessica Darling for help with sample procurement and processing. John McGeehin provided assistance with AMS ${ }^{14} \mathrm{C}$ analyses. We are grateful to Nial Slowey and William Bryant (TAMU), Rusty Lotti (LDEO), Arman Silva and Steven Carey (URI) for providing material. The LDEO core lab is funded under NSF Grant OCE97-11316 and Office of Naval Research Grant N00014-96-10186. The URI core lab is funded under NSF Grant OCE-0002226. This 
work was supported by the USGS Earth Surface Dynamics Program.

\section{REFERENCES}

Blow, W.H., 1969. Late middle Eocene to Recent planktonic foraminiferal biostratigraphy. In: Bronnimann, P. and Renz, H.H., (Eds.), Proceedings of the First Planktonic Conference: Leiden (E.J. Brill), p. 199-422.

Brunner, C.A., 1979. Distribution of planktonic foraminifera in surface sediments of the Gulf of Mexico. Micropaleontology, 25(3): 325-335.

Brunner, C.A., 1982. Paleoceanography of surface waters in the Gulf of Mexico during the Late Quaternary. Quaternary Research, 17: 105-119.

Brunner, C.A. and Cooley, J.F., 1976. Circulation in the Gulf of Mexico during the last glacial maximum. Geological Society of America, Bulletin, 87: 681-686.

CLIMAP, 1976. The surface of the ice-age earth. Science, 191: 1131-1137.

CLIMAP, 1981. Seasonal reconstructions of the Earths surface at the last glacial maximum. In: McIntyre, A., Map and Chart Series 36, Geological Society of America.

CLIMAP, 1984. The last interglacial ocean. Quaternary Research, 21: 123-224.

Cline, R. and Hays, J. (eds.), 1976. Investigation of Late Quaternary paleoceanography and paleoclimatology. Geological Society of America Memoir 145.

Dowsett, H.J., Barron, J.A., Poore, R.Z., Thompson, R.S., Cronin, T.M., Ishman, S.E., and Willard, D.A., 1999. Middle Pliocene paleoenvironmental reconstruction: PRISM2. USGS Open File Report 99-535, http:// pubs.usgs.gov/openfile/of99$535 /$.

Dowsett, H.J., Brunner, C.A., Poore, R.Z. and Boisvert, B.A., 2002. Gulf of Mexico planktic foraminifer core-top data. EOS Transactions AGU, 83(19), Spring Meeting Supplement, Abstract GS41A-09.

Dowsett, H.J. and Poore, R.Z., 2001. Planktic foraminifer census data from the northwestern Gulf of Mexico. U.S. Geological Survey Open File Report 01-108: 1-6.

Imbrie, J. and Kipp, N.G., 1971. A new micropaleontological method for quantitative paleoclimatology: Application to a late Pleistocene Caribbean core. In: Turekian, K.K. (ed.), The Late Cenozoic Glacial Ages. New Haven, Yale University Press: 72-181.

Kennet, J.P. and Srinivasan, S., 1983. Neogene planktonic foraminifera: a phylogenetic atlas. Hutchinson Ross, New York, 265p.

Murray, J., 1995. Microfossil indicators of ocean water masses, circulation and climate, In, Bosence, D. and Allison, P. (eds.), Marine palaeoenvironmental analysis from fossils, Geological Society Special Publication 83: 245-264.

Parker, F.L., 1962. Planktonic foraminiferal species in Pacific sediments. Micropaleontology, 8: 219-254.

Parker, F.L., 1967. Late Tertiary biostratigraphy (Planktonic Foraminifera) of tropical Indo-Pacific deep-sea cores: Bulletins of American Paleontology, 8: 115-208. 
Poore, R.Z., Dowsett, H.J.,Verardo, S., and Quinn, T.M., in review. Millenial to century scale variability in Gulf of Mexico Holocene climate records. Paleoceanography.

Roberts, M., Bench, G., Brown, T., Caffee, M., Finkel, R., Freeman, S., Hainsworth, L., Kashgarian, M., McAninch, J., Proctor, I., Southon, J., and Vogel, J., 1997. The LLNL AMS Facility, In: Jull, J., Beck, J., and Burr, G., Eds., Proceedings of the Seventh International Conference on Accelerator Mass Spectrometry, Tucson, AZ, USA, North Holland Press, p. 57-61.

Stuiver, M., et al., 1998. INTCAL98 Radiocarbon age calibration. Radiocarbon 40(3): 1041-1083. 